observed to about one hour after the first after-glow had disappeared below the horizon. The exact moment of this disappearance has been more difficult to determine than in the earlier observations where darkness followed; as recently the heavens and the earth have been reilluminated just as the natural night would have begun.

T. STORY-MASKELYNE

Salthrop, January I3

As the "halo" exactly opposite the sun, reported by Mr. T. W. Backhouse in NATURE, January Io (p. 25r) may prove to be of considerable importance, I beg to add my observations of it on the I2th. I had noticed a mass of ruddy colour under the given conditions, previously, but had not detected its strange nature. The sunset on the $\mathrm{i} I$ th was very fine. The 12th, until after sunset, was cloudless, except for the hazy masses which seem to precede every sunrise, and, more especially, sunset, at present. Our sunshine record is an unbroken scorch from 9.15 a.m. to $2.52 \mathrm{p} . \mathrm{m}$. (sun seen clear of horizon at 8.26, and touched at 4.0); I doubt if, previously, we have recorded even five hours in early January. At 7.45 a.m. on the 12th (sun rose at 8.22) the cloud-glow bad turned to silvery green below, and rose from $15^{\circ}$ to $30^{\circ}$ in the south east. At 7.47 the rose reached $60^{\circ}$, but was fainter. I first noticed the "halo" at 7.52. It was then so well defined that, calling a lady's attention by asking what she saw there, she spoke of it as "a broad rainbow." Position, by compass, $30^{\circ}$ north of west. It was a semicircle situated $10^{\circ}$ above the horizon, standing on the dark gray arch of dawn, Jupiter being on a line with the base of the left end of the rosy arch. The inner arc of this measured $10^{\circ}$, and the outer $24^{\circ}$ in radius, but it spread ont to $30^{\circ}$ at the base. The centre was of the same blue as the sky to the right and left of the rosy semicircle, above the gray. The base, sinking faster than Jupiter, spread out so that, at 8 o'clock, the arch having now broken above, its outline was rather like a railway chair. The base now reached from west-north-west to north-north-west by north. After sunset there were signs of a sinilar phenomenon, but clouds prevented certainty.

Is not fifty miles an und rrestimate for the altitudes of the light-reflecting material? If Mr. Symons is nearer the mark in his suggestion ( 100 to 200 miles), then more than half of the eastward velocity of the original erupted dust is accounted for by retardation, due to matter having velocity belonging to an earth radius of 4000 miles, revolving in a circle of 4100 to 4200 miles radius. Would it need an eruptive force of more than two to four miles per second (six to twelve times greater than a cannon ball) to attain such altitudes? The constant uprush would minimise the air-resistance enormously.

York, January 14

J. Edmund Clark

P.S. - Tanuary 15.-This morning, at 7.47, the "balo" began to form, but was not nearly as perfect as on the 12 th. The arch (upper part only) was rayed, as if it were the opposite point of sinht for rays from the sun. All over before 8 , or fully twenty minutes before sunrise.-J. E. C.

W1TH reference to Herr Wetterhan's inquiry as to the absence of the sky-glow in a clear sky at other places than Freiburg on the morning of January II, I find that at San Remo, in Northern Italy, where $I$ spent the week ending on that day, a similar falling off of effect occurred at the same time. The sunrise was "very fine, but nothing to cumpare with the sunset of yesterday," and "the filmy streaks were very thin, and stretched this morning from south-west by south to nortll-east by north." Nevertheless there was the strange bluish-white glare above the eastern horizon, casting shadows, and a thin pink film up to about $75^{\circ}$ at $28 \mathrm{~min}$. before sunrise. The sunset glow of thi day and of the day before was magnificent, the procession of colours beginning about $15 \mathrm{~min}$. after sunset, and lasting a full hour. I see that your Constantinople correspondent also mentions the sunset of the IIth as a remarkably fine one. The air on the Ioth, not the IIth, as at Freiburg, was wonderfully transparent at San Remo, the whole range of Corsican mountains, over eighty miles distant, standing out sharply for 15 min. before and after sunrise, and the sun himself bursting forth in great splendour from below the sea line.

London, January 19

F. A. R. RUSSELL

\section{Unconscious Bias in Walking}

SOME ten or twelve years ago I made some experiments upon the subject of Mr. Larden's letter in NATURE (Jan. 17, p. 262), namely, unconscious bias in walking. Tho experiments werc not numerous, but they left no doubt in my mind as to the cause of divergence from a straight path. My notes were sent, at my father's suggestion, to the late Mr. Douglas Spalding, who was about to undertake experiments on the curious power which animals have of finding their way. I rather think he made some trials with pigs, but I believe he never published anything on the subject. In stating my results I am compelled therefore to rely on memory only.

I began with walking myself, and getting various friends to walk, with eyes shut in a grass field. We all walked with amazing crookedness in paths which were not far removed from circles. I myself and $\mathrm{Mr}$. Galton on the first trial described circles of not more than fifty yards in diameter, although we thought we were going straight, and afterwards I was generally unable to impose a sufficiently strong conscious bias in one direction to annul the unconscious bias in the other. I believe we all diverged to the right excepting one of us who was strongly left-handed.

I then got eight village schoolboys, from ten to twelve years of age, and offered a shilling to the boy who should walk straightest blindfold. Before the contest, however, I dusted some sawdust on the ground, and after making each of the boys walk over it, measured their strides from right to left and left to right. They were also made to hop, and the foot on which they hopped was noted ; they were then made to jump over a stick, and the foot from which they sprang was entered; lastly, they were instructed to throw a stone, and the hand with which they threw was noted. Each of these tests was applied twice over.

I think they were all right-handed in throwing a stone, but $I$ believe that two of them exhibited some mark of being partly left-handed. The six who were totally right-handed strode longer from left to right than from right to left, hopped on the left leg, and rose in jumping from that leg. One boy pursued the opposite course, and the last walked irregularly, but with no average differ: nce between his strides. When told to hop, he hopped on one leg, and in the repetition on the other, and I could not clearly make up my mind which leg he used most in jumping. When I took them into the field, I made the boys successively take a good look at a stick at about forty yard. distance, and then blindfolded them, and started them to walk, guiding them straight for the first three or four paces. The result was that the left-legged boys all diverged to the right, the right-legged boys diverged to the left, and the one who would not reveal himself won the prize. The trial was repeated a second time with closely similar results, although the prizewinner did not walk nearly so straight on a second trial.

I also measured the strides of myself and of some of my friends, and found the same connection between divergence and comparative length of stride. My own step from left to right is about a quarter of an inch longer than from right to left, and I am strongly right-handed.

Comment on the experiments seems needless, and they entirely confirm Mr. Larden in his view.

It seems to be generally held that right-leggedness is commoner than the reverse ; this I maintain to be incorrect. I believe that nine out of ten strongly right-handed persons are left-legged. Every active effort with the right hand is almost necessarily accompanied by an effort with the left leg, and a right-handed man is almost compelled to use his left leg more than the other. I believe that Sir Charles Bell considered that men were gene rally right-legged, and sought to derive the custom of mounting a horse from the left side from the fact that the right leg is stronger than the other. I suggest as almost certain that we mount on that side because the long sword is necessarily worn on the left, and would get between our legs if we went to the off-side of the horse. Some of your readers may perhaps be able to tell us whether the Chinese do not wear their short swords on the right and mount their horses from the right.

I will not hazard a conjecture as to why the rule of the road in Great Britain, and inside of the towns of Florence and of Salzburg (?), is different from that adopted by the rest of the world. For an armed horseman the English rule is, I presume, more advantageous, both for attack and defence.

January 20

G. H. DARWIN

THE question whether a man will walk to the right or left in a mist, in darkness, or if blindfolded, has led to no little controversy and dispute. Almost every conceivable reason has had its advocates for the fact that some men persistently turn to the 